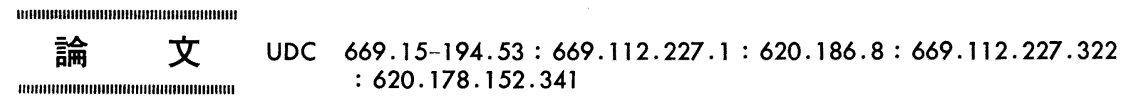

\title{
共析鋼の焼入性におよぼすオーステナイト結晶粒径の影響*
}

\author{
梅本 実**.小松原 望***。田村 今男****
}

\section{Effect of Austenite Grain Size on the Hardenability of Eutectoid Steel}

\author{
Minoru Umemoto, Nozomi Komatsubara, and Imao Tamura
}

\begin{abstract}
Synopsis:
As a first step to obtain a theoretical prediction of hardenability based upon the theories of phase transformation, the effect of austenite grain size on the hardenability of eutectoid steel is examined.

The effect of austenite grain size on the isothermal pearlite transformation curves were first measured.

The obtained results were analysed according to the Cahn's theory and the volume fraction of pearlite can be expressed as $X=1-\exp \left(-1.31 \times 10^{-5} \times \frac{t^{4}}{d^{\mathbf{1 . 7 6}}}\right)$. This result indicates that the pearlite transformation in the steel in present study procceeds by nucleation and growth and dominant nucleation site is grain edge. Step quenching experiments indicates that additivity rule is almost holds.

Using these experimental data, the effect of austenite grain size on the ideal critical diameter was calculated as $D_{\mathrm{I}} \propto d^{\mathbf{0 . 2 2}}$. The relation between the ideal critical diameter and the diameter of the bar having any amount of martensite at the center is also calculated.
\end{abstract}

\section{1. 緒言}

鋼の焼入性を定量的に予測する事に対して，古くから 種々な試みがなされてきたが1) 4)，その多くは GROSsMANN によつて代表されるよらな比較試験によるもので あり多くの実験結果から帰納的に各因子の影響を取り出 し，相加又は相乗により焼入性を計算するものであつ た.これらの方法は焼入硬化深度を予測する一応の目安 として，これまで工業的に使用されてきたが，精度上の 難点や適用範囲の制限があり,より精度の高い焼入性の 予测が望まれていた。

ところで近年相変態についての熱力学や核生成·成長 理論が発展し多くの論文が発表されており5) 10), これら の理論を焼入性の問題に応用することにより, 従来の経 験則に代わつてより精度の高い焼入性の予測がおこなわ れらると考えられる．しかし相変態理論に基ついて焼入 性を取り扱つた研究はほとんど見られない11)。そこで本 研究は焼入性を理論的に予測する目的からまず共析鋼を とりあげ, オーステナイト結晶粒径が等温パーライト変 態の速度式にいかなる影響を与えるのかを数量的に表現 し, step quench 法によりパーライト変態の kinetics
における加算性の問題12)を調べ，等温変態で得られたデ 一タを連続冷却変態に変換する方法を検討し，これらの 実験によつて得られたデータを基にコンピュータを使つ て共析鋼の理想臨界直径に対するオーステナイト結晶粒 径の影響を定量的に表現することを試みた。

\section{2. 実 験 方 法}

供試材は SKD6 に近い共析鋼でその化学組成を Table 1 に示す. 本研究にこの鋼を使用したのはこの鋼 の変態の潜伏期が非常に長くまた变態の進行も非常にお そいため，焼入れ瞬間からその温度になるまでの時間な ぞ，実験に伴う時間の消費をほとんど無視できる利点が

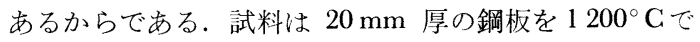
$20 \mathrm{~h}$ 真空中で均一化し，熱間及び冷間圧延により 1.6 $\mathrm{mm}$ 厚さの薄板にし $1.5 \mathrm{~mm} \times 7.5 \mathrm{~mm} \times 1.6 \mathrm{~mm}$ の大き さに切り出した.

Table 1. Chemical composition of specimen (wt \%).

\begin{tabular}{|c|c|c|c|c|c|c|c|c|c|c|}
\hline $\mathrm{C}$ & $\mathrm{Si}$ & $\mathrm{Mn}$ & $\mathrm{P}$ & $\mathrm{S}$ & $\mathrm{Ni}$ & $\mathrm{Cr}$ & $\mathrm{Mo}$ & $\mathrm{V}$ & $\mathrm{Cu}$ & $\mathrm{Fe}$ \\
\hline 0.35 & 0.89 & 0.43 & 0.013 & 0.007 & 0.006 & 5.50 & 1.20 & 0.52 & 0.03 & bol \\
\hline
\end{tabular}

* 昭和 53 年 10 月本会講演大会にて発表 昭和 54 年 6 月 4 日受付 (Received June 4, 1979)

** 京都大学工学部 Ph. D. (Faculty of Engineering, Kyoto University, Yoshidahonmachi Sakyo-ku Kyoto 606)

*** 京都大学大学院 (Graduate School, Kyoto University)

**** 京都大学工学部 工博 (Faculty of Engineering, Kyoto University) 

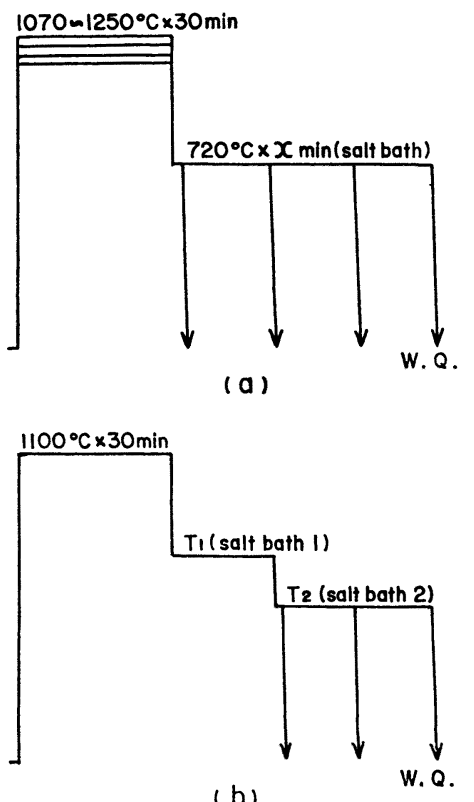

Fig. 1. Heat treatments. (a) to study the effect of austenite grain size on pearlite transformation, (b) to study the rule of additivity by step quenching.

等温パーライト変態におよぼすオーステナイト結晶粒 度の影響についての研究にあたつては Fig.1 (a) に示 すよらに $1070^{\circ} \mathrm{C}$ から $1250^{\circ} \mathrm{C}$ の間の種々の温度で $30 \mathrm{~min}$ オーステナイト化し*その後直ちに所定の温度 に保つた塩浴中に焼入れ，所定の時間パーライト変態を おこさせ水焼入れした. 次にパーライト変態の kinetiscs における加算性の研究にあたつては Fig.1（b）に示す ように $1100^{\circ} \mathrm{C}$ で $30 \mathrm{~min}$ オーステナイト化し, 温度 $T_{1}$ に保つた塩浴 1 に焼入れ所定の時間保持後温度 $T_{2}$ に保つた塩浴 2 に焼入れ, 種々の時間保持後水焼入れを おこなつた。

パーライトの変態量の測定にあたつては試料表面を研 磨後過酸化水素とふつ酸の混 合 液 $\left(\mathrm{H}_{2} \mathrm{O}_{2} 80 \mathrm{cc}+\mathrm{H}_{2} \mathrm{O} 15\right.$ cc + HF 5cc）および $5 \%$ ナイタールで腐食し画像解析 装置で変態量を定量した。

\section{3. 実 験 結 果}

\section{$3 \cdot 1$ 等温パーライト変態におよぼすオーステナイト 結晶粒度の影響}

本研究に使用した鋼の等温パーライト変態の開始曲線

* これらのオーステナイト化した武料においては，光顕および電顥で炭

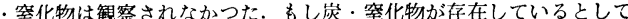
もきわめて微量であり変態の kinetics への影響はほとんどないと思 われる。

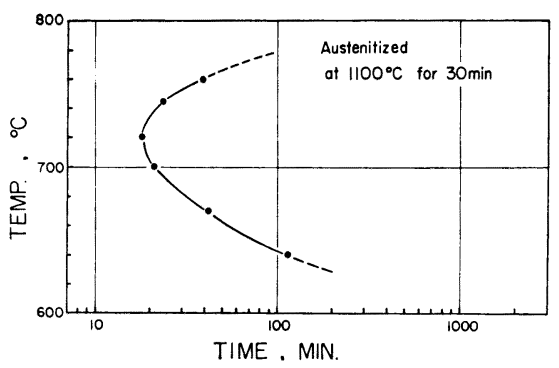

Fig. 2. TTT diagram of DAC steel showing the time at which pearlite is first detected by optical microscope.

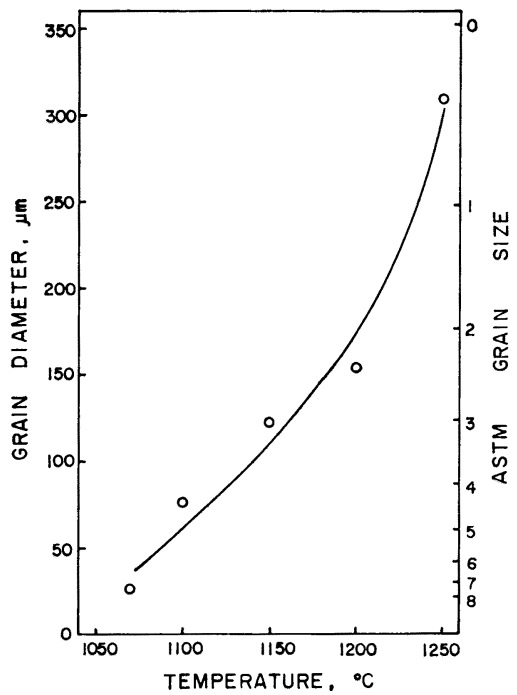

Fig. 3. Effect of the austenitizing temperature on the austenite grain size.

をFig. 2 に示す.これは $1100^{\circ} \mathrm{C}$ で $30 \mathrm{~min}$ オース テナイト化した試片を種々の温度に保持した塩浴中に焼 入れ，光学顕微鏡で始めてパーライトが観察された時を 変態開始時間として図示したものである.この鋼のパー ライト変態開始線は $720^{\circ} \mathrm{C}$ 付近に nose をもつ典型的 な $\mathrm{C}$ 曲線を示しており，変態開始までの時間は Fe-C の 数秒といらのに比べ非常に長くそれが最も短い nose 付 近でも約 $20 \mathrm{~min}$ もかかることがわかる.

Fig. 3 はこの鋼を種々な温度で $30 \mathrm{~min}$ オーステナイ ト化した時のオーステナイト粒径の変化を示している. オーステナイト化温度を $1070^{\circ} \mathrm{C}$ から $1250^{\circ} \mathrm{C}$ まで変 化させると粒径は $27 \mu \mathrm{m}$ から $300 \mu \mathrm{m}$ 一と 10 倍以上 にも変化している. 本研究では $1070,1100,1200$ そ して $1250^{\circ} \mathrm{C}$ の 4 つ温度でオーステナイト化をおこ ならことによりオーステナイト粒径を変化させた。 オー 


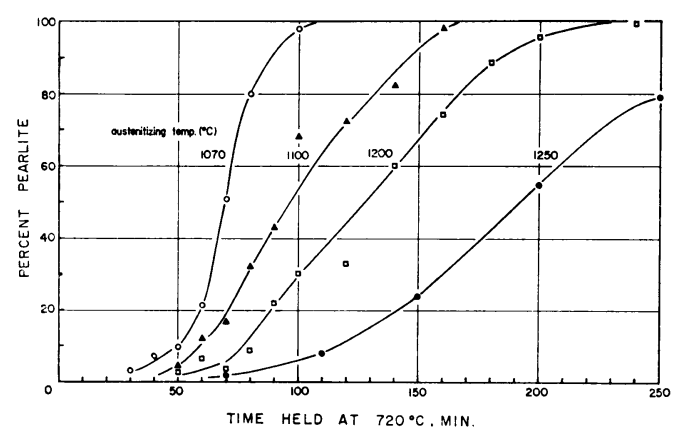

Fig. 4. Isothermal reaction curves for specimens austenitized at four different temperatures.

ステナイト化後のパーライト変態の温度については連続 冷却変態の立場から考えて変態の進行が最も速い nose 付近の $720^{\circ} \mathrm{C}$ を選んだ.

Fig.4 は 4 つの異なつたオーステナイト化温度でオー ステナイト化後 $720^{\circ} \mathrm{C}$ で種々の時間保持した試料のパ ーライト变態曲線を示している.オーステナイト化温度 が高くなるにつれ，すなわちオーステナイト結晶粒径が 大きくなるにつれ，変態曲線が大きく長時間側へ移動し ている.このよらにオーステナイト結晶粒径が大きくな るとパーライト変態の進行が遅くなるといらことはこれ まで定性的にはよく知られていたことである，そこでこ の得られた結果をもとに $\mathrm{CAHN}^{5)}$ の理論に従つてパーラ イトの核生成・成長機構について考察し，オーステナイ 卜結晶粒度の影響を定量的に表現することを試みた。

$\mathrm{CAHN}^{5)}$ は粒界核生成型反応の速度論に関して，核生 成場所を grain surface, edge, corner の 3 つの場合に わけて考察している.そしてそれぞれの場合において変 態の進行は site saturation，つまり変態のごく初期段階 にすべての核ができてしまい，その後は成長だけで変態 が進む場合と, 変態が核生成を伴いながら進行する場合 (ここでは便宜的に nucleation and growth と呼ぶ）の 2 つの特徵的なケースに分けられ，それぞれにおいて変 態の進行は Table 2 に示すような式で表されることを 示した。ただし核生成速度 $I_{\mathrm{s}} ， I_{\mathrm{e}}, I_{\mathrm{c}}$ は時間に依存せず 一定であるとしている，そこで本研究での結果がこれら のらちのどの式にあてはまるのかを考察していく.まず 変態率(体積率)の時間依存性に着目すると, site saturation の場合核生成場所が surface, edge, corner となる につれ exponential の中の項が $1,2 ， 3$ 乗と変化し， nucleation and growth の場合は核生成 site の種類によ らず $t$ の 4 乗で変態が進むことがわかる. そこで本研究 で得られた変態量の時間変化を Fig. 5 に示すように縦
Table 2. Summary of the rate laws for different nucleation mechanisms and for different nucleation sites.

\begin{tabular}{l|c|c}
\hline \multicolumn{1}{c|}{ Site } & Site Saturation & $\begin{array}{c}\text { Nucleation and } \\
\text { Growth }\end{array}$ \\
\hline Surface & $X=1-e^{-2 S G t}$ & $X=1-e^{-1 / 3 \pi I_{\mathrm{s}} S G^{3} t^{4}}$ \\
\hline Edge & $X=1-e^{-\pi L G^{2} t^{2}}$ & $X=1-e^{-1 / 3 \pi I_{\mathrm{e}} L G^{3} t^{4}}$ \\
\hline Corner & $X=1-e^{-4 / 3 \pi C G^{3}: 3}$ & $X=1-e^{-1 / 3 \pi I_{\mathrm{e}} C G^{3} t^{4}}$ \\
\hline
\end{tabular}

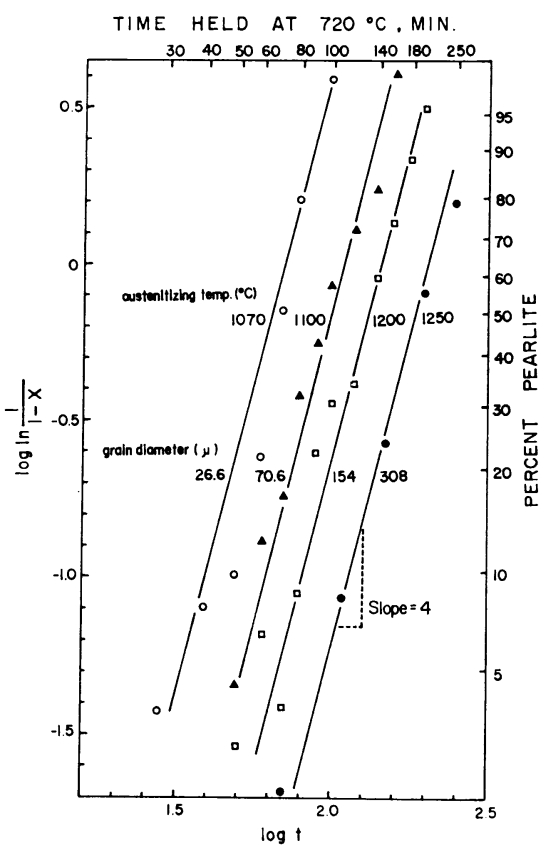

Fig. 5. $\log \ln \frac{1}{1-X}$ as a function of $\log t$. Slope indicates the time dependence of the isothermal reaction.

軸が $\log \ln \frac{1}{1-X}$, 横軸が $\log t$ のグラフにプロット した．この図から，パーライト変態量の時間変化はすべ てのオーステナイト結晶数度において傾き 4 の直線にほ ぼのることが判明した．このことは Table 2 の分類に 従うと変態が nucleation and growth で進行している ことを意味している.

nucleation and growth の場合について CAHN は変 態率 $X$ は一般的に,

$$
X=1-e^{-1 / 3 \pi \dot{N} G^{3} t^{4}}
$$

で表されるとしている，ここで $N$ は核生成速度で $G$ は成 長速度である。この式からある変態率 $X$ に達するまでの 時間 $t_{\mathrm{X}}$ は $\left(\dot{N} G^{3}\right)^{-1 / 4}$ に比例することがわかる。この 実験ではすべて $720^{\circ} \mathrm{C}$ の一定温度で変態させているの 
Table 3 The dependences of $t_{x}$ on $d$ for three different nucleation sites when the isothermal reaction proceeds by nucleation and growth.

\begin{tabular}{l|c|c|c}
\hline \multicolumn{1}{c|}{ Site } & $\begin{array}{c}\text { Nucleation } \\
\text { rate }\end{array}$ & $\begin{array}{c}d \\
\text { dependence }\end{array}$ & $t_{\mathbf{x}}$ \\
\cline { 1 - 1 } Surface & $\dot{N}_{\mathrm{s}}=I_{\mathrm{S}} S$ & $S \propto d^{-1}$ & $t_{x} \propto d^{\mathbf{1} / \mathbf{4}}$ \\
Edge & $\dot{N}_{\mathrm{e}}=I_{\mathrm{e}} L$ & $L \propto d^{-2}$ & $t_{x} \propto d^{2 / 4}$ \\
Corner & $\dot{N}_{\mathrm{c}}=I_{\mathrm{e}} C$ & $C \propto d^{-3}$ & $t_{x} \propto d^{3 / 4}$ \\
\hline
\end{tabular}

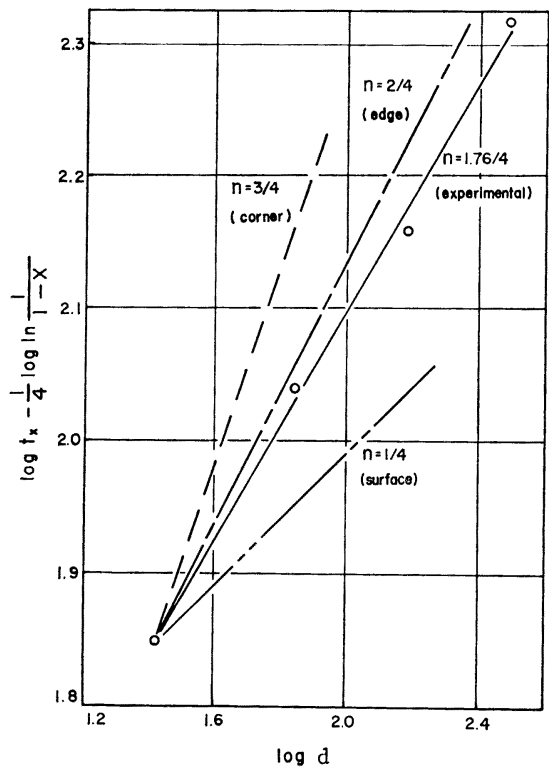

Fig. 6. $\log t_{\mathrm{X}}-\frac{1}{4} \log \ln \frac{1}{1-X}$ as a function of $\log$ $d$. Slope indicstes the dependence of $t_{\mathrm{X}}$ on $d$.

でGは一定となり変態曲線に打ける相異は $\dot{N}$ のみに依存 していることになる。核生成場所が grain surface の場 合，核生成速度 $\dot{N}_{\mathrm{S}}$ は grain surface の単位面積あた りの核生成速度 $I_{\mathrm{S}}$ と単位体積あたりの grain surface の面積の積となる，単位体積あたりの grain surface の 面積は結晶粒径 $d$ のー 1 乗に比例するので， ある変態量 $X$ に達するまでの時間 $t_{\mathrm{X}}$ は結晶粒径の $1 / 4$ 乗に比例す ることになる. 同様にして edge と corner について粒 径の影響を考察し整理したものを Table 3 亿示す。こ れからある変態量 $X$ に達するまでの時間 $t_{\mathrm{X}}$ は核生成場 所が surface, edge, cornerのいずれであるかによつて 結晶粒径 $d$ の $1 / 4 ， 2 / 4 ， 3 / 4$ 乗にとれぞれ比例するこ とがわかる. そこで本研究での結果を Fig. 6 のように プロットし， $t_{\mathrm{X}}$ 一の結晶粒径の依存性を調べると，デ 一タの傾きがほぼ $2 / 4$ の直線にのつており, Table 3 に 示した結果からみてパーライトの主たる核生成場所が

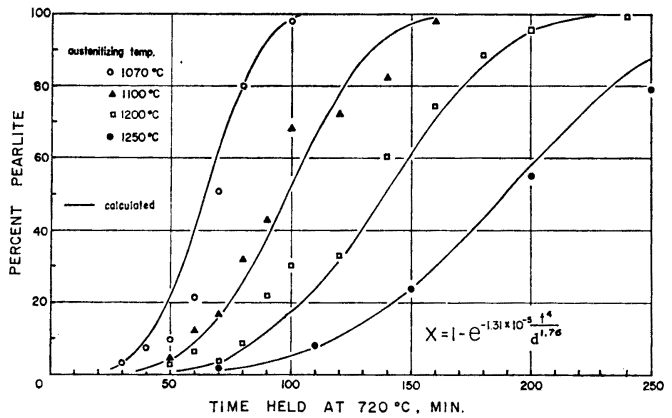

Fig. 7. Galculated isothermal reaction curves for four different austenite grain sizes.

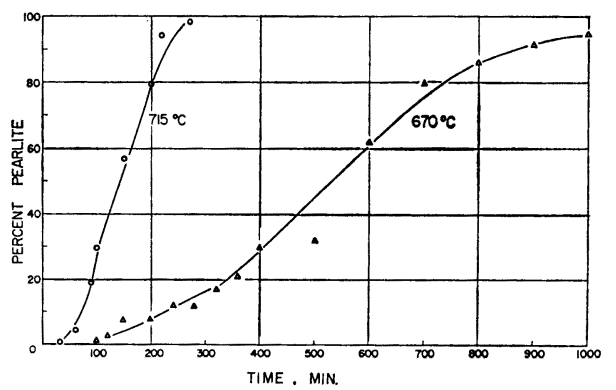

Fig. 8. Isothermal reaction curves at 715 and 670 ${ }^{\circ} \mathrm{C}$.

grain edge であると理解できる.

以上，等温パーライト変態に対する時間と結晶粒径の 依存性を整理した結果, 本研究で使用した鋼のパーライ 卜変態率 $X$ は

$$
X=1-\exp \left(-1.31 \times 10^{-5} \times \frac{t^{4}}{d^{1.76}}\right) .
$$

で与えられることが判明した。 ここで $t$ は min 単位, $d$ は $\mu$ m単位で与えている. Fig. 7 は (2) 式を用いて本 研究でのそれぞれのオーステナイト結晶粒径に対するパ ーライト変態曲線を計算したものであるが，（2)式が実 験值のよい近似であることがわかる.

\section{2 パーライト変態の kinetics における加算性に วいて}

等温パーライト変態を連続冷却変態へ拡張する目的 で, step quench 法を用いて変態の kinetics に打ける 加算性について検討した. step quench には nose 付近 の $715^{\circ} \mathrm{C}$ と, 変態の潜伏期がおよそその 2 倍にあたる $670^{\circ} \mathrm{C}$ を選んだ.

Fig. 8 に $715^{\circ} \mathrm{C}$ およ゙ $670^{\circ} \mathrm{C}$ におけるパーライト 変態曲線を示す. $715^{\circ} \mathrm{C}$ に扣いてはパーライト反応は速 く $300 \mathrm{~min}$ までに変態はすべて完了しているが, $670^{\circ} \mathrm{C}$ 

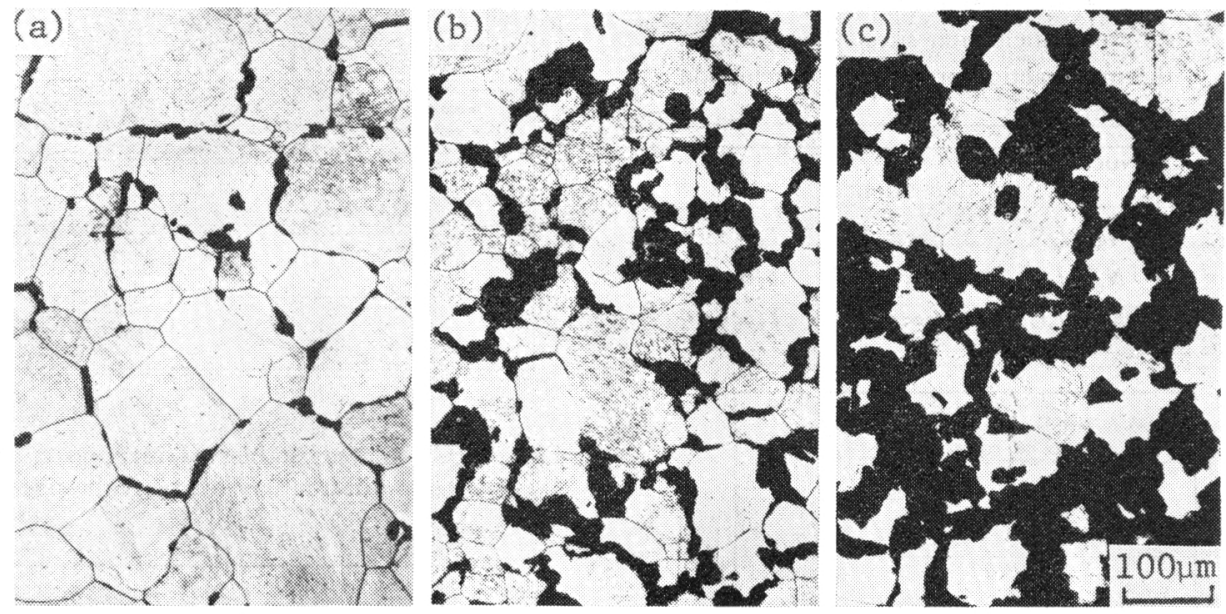

Photo. 1. Optical micrographs showing the progress of transformation at $715^{\circ} \mathrm{C}$. (a) $50 \mathrm{~min}$, (b) $80 \mathrm{~min}$, (C) $150 \mathrm{~min}$.
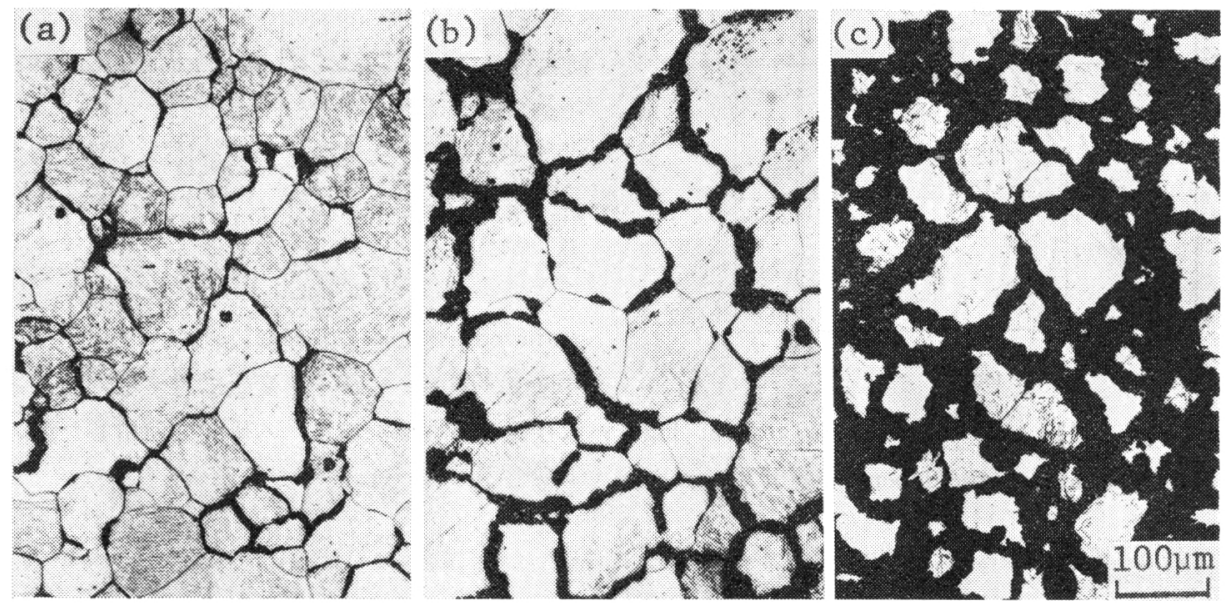

Photo. 2. Optical micrographs showing the progress of transformation at $670^{\circ} \mathrm{C}$.

(a) $150 \mathrm{~min}$, (b) $300 \mathrm{~min}$, (c) $600 \mathrm{~min}$.

で保持したものでは変態が完了するのに $1000 \mathrm{~min}$ 以上 要する事がわかる. 次に各温度での変態の進行を光学顕 微鏡により観察したものを Photos. 1, 2 飞示す. Photo. 1 は $715^{\circ} \mathrm{C}$ でそれぞれ 50, 80, $150 \mathrm{~min}$ 保持した時の 光学顕微鏡組織であるが，パーライトはオーステナイト 粒内に向かつて塊状を呈しながら成長している. Photo. 2 は $670^{\circ} \mathrm{C}$ で保持した場合で，パーライトは粒界にそ つてフィルム状に生成し, 粒内への成長よりも粒界での 核生成がより顥著であることがわかる，これは変態温度 の高いものでは過冷度が少なく従つて変態の駆動力が小 さく核生成速度が拈そいが，成長速度の方は高温程桩散 速度が速くなるので速くなる. 従つて高温では核の数が
少なく成長が活発で，低温では核の数は多く成長は抢そ いということになりこれが観察された変態の仕方の相異 の要因と考光られる.

変態の kineticsに打汀る加算性を調べるにあたつて変 態を潜伏期と変態開始後に分汁て取り扱つた。ただしこ こで潜伏期というのは光学顕微鏡観察によりパーライト 変態が認められるまでの時間とした。 まず $715^{\circ} \mathrm{C}$ と $670^{\circ} \mathrm{C}$ のどららか一方の温度で潜伏期を消費させたのち もら一方の温度で変態を進行させ潜伏期の消費した温度 がその後の変態に与える影響について調べた。 Fig.9 は その時の熱処理を模式的に示したもので（a）は $715^{\circ} \mathrm{C}$ で潜伏期を消費後 $670^{\circ} \mathrm{C}$ で変態を進行させた場合を， 

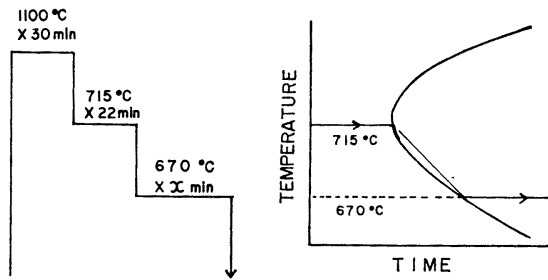

(a)
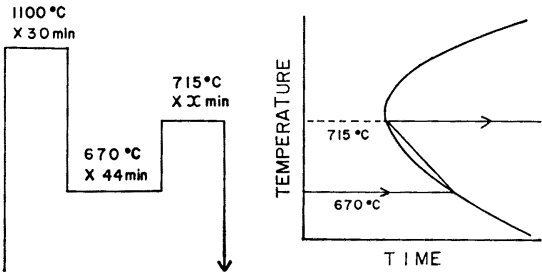

(b)

Fig. 9. Heat treatments of step quenching.

(a) consume incubation period at $715^{\circ} \mathrm{C}$ and then transform at $670^{\circ} \mathrm{C}$, (b) consume incubation period at $670^{\circ} \mathrm{C}$ and then transform at $715^{\circ} \mathrm{C}$.

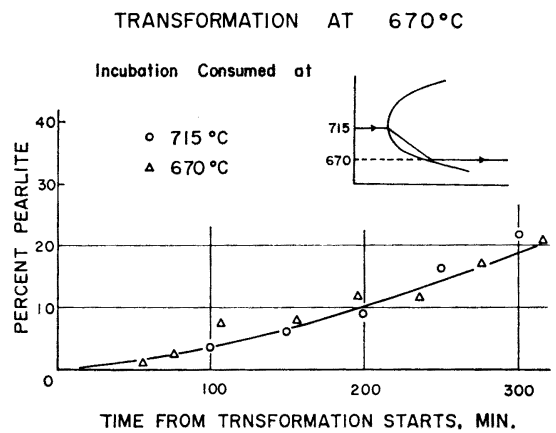

(a)

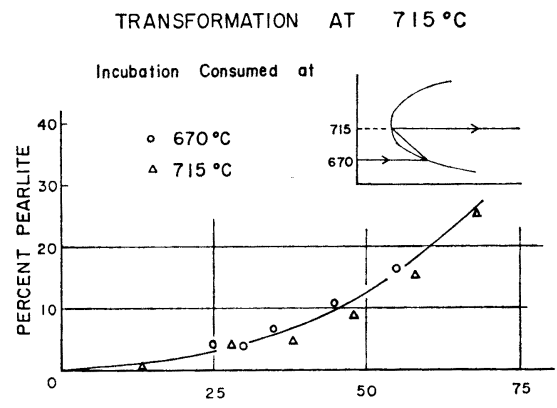

TIME FROM TRNSFORMATION STARTS, MIN

(b)

Fig. 10. Percent pearlite as a function of time after transformation starts.

(a) transformation at $670^{\circ} \mathrm{C}$, (b) transformation at $715^{\circ} \mathrm{G}$. （b ）は $670^{\circ} \mathrm{C}$ で潜伏期を消費後 $715^{\circ} \mathrm{C}$ で变態を進行 させた場合を示している.Fig.10（a）は $670^{\circ} \mathrm{C}$ で変 態をおこさせた場合の結果でパーライト变態量を $670^{\circ} \mathrm{C}$ で変態が開始してからの時間, つまり各温度での潜伏期 をさし引いた時間に対してプロットしている。 ○印は $715^{\circ} \mathrm{C}$ で潜伏期を消費後 $670^{\circ} \mathrm{C}$ で変態を進行させた場 合を， $\triangle$ 印は $670^{\circ} \mathrm{G}$ で潜伏期を消費後そのまま変態を 進行させた場合をそれぞれ示している．このグラフより 両者の間にはほとんど差が認められないことがわかる. 同様にして $715^{\circ} \mathrm{C}$ で変態を進行させた場合を. Fig.10 （b）に示すがこの場合も Fig.10（a ） と同様, 潜伏期を 消費した温度の影響はほとんど認められないことがわか る.

このようにパーライト変態においては潜伏期をどの温 度で消費したかは，その後の変態進行過程に対してほと んぞ影響を与えない，つまり加算則が成り立つことが明 らかになつた。

次にある程度変態が進んだ後変態温度を変更させた場 合のパーライト変態の進行過程を調べた. Fig. 11 はそ

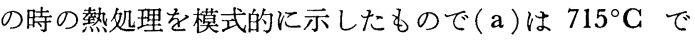
変態を一部おこさせて，その後 $670^{\circ} \mathrm{G}$ で変態を継続さ せる場合，(b)は $670^{\circ} \mathrm{G}$ で変態を一部おこさせてから $715^{\circ} \mathrm{C}$ で継続させる場合を示している。 まず $715^{\circ} \mathrm{C}$ で $100 \mathrm{~min}$ 保持しパーライトを $29 \%$ 変態させた後 $670^{\circ} \mathrm{C}$ に移した場合 $670^{\circ} \mathrm{C}$ での変態の進行はもし加算則が成 り立つならばパーライト量が $29 \%$ のところからもとの
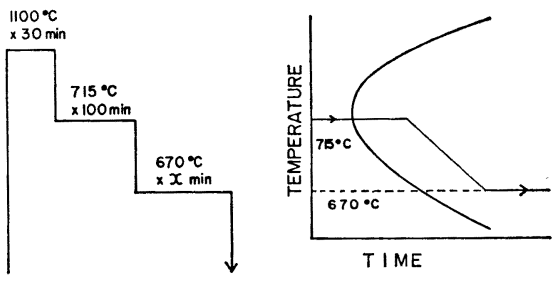

(a)
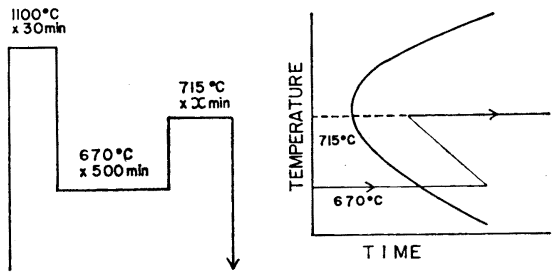

(b)

Fig. 11. Heat treatments of step quenching. $\mathrm{Re}-$ action temperature is changed after a certain amount of transformation is completed. (a) from 715 to $670^{\circ} \mathrm{C}$, (b) from 670 to $715^{\circ} \mathrm{G}$. 


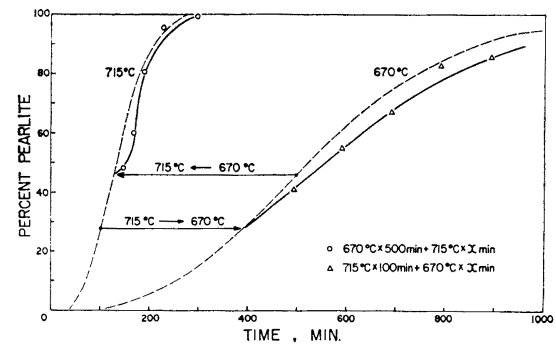

Fig. 12. Comparison of isothermal reaction curve with regular transformation (dashed line) and that of step quenched (solid line).

$670^{\circ} \mathrm{C}$ での変態曲線と同じになるはずである，そこでこ こを原点にとり $670^{\circ} \mathrm{C}$ での保持時間と变態量をプロッ トしたのが Fig.12 の右側の実線である。これを最初か ら $670^{\circ} \mathrm{C}$ で変態させた場合（破線）と比較すると変態 温度を途中で変更させた場合の方がわずかに長時間側に ずれるが (10\% 未満) 全体としてはよく一致しているこ とがわかる，変態温度を $670^{\circ} \mathrm{C}$ から $715^{\circ} \mathrm{C}$ に变更し た場合についても同样に比較するとこれも途中で変態温 度を変更させた場合の方がわずかに長時間側にずれるが 全体としてはよく一致していることがわかる.

以上 step quench 法によりパーライト変態の kinetics に拉ける加算性について調べた結果，变態途中で温 度を変化させると変態の進行はわずかに遅くなるが，加 算性がほぼ成り立つことが判明した。

\section{3 理想臨界直径 $D_{1}$ におよぼすオーステナイト結晶 粒度の影響}

3.1 亿打いて nose 温度におけるパーライト変態の速 度式に括よぼすオーステナイト結晶粒径の影響を数式化 し，3.2 において变態途中で温度を変化させた場合パーライト変態が加算則をほぼ満足することを示した，そこ でこれらの結果を用いて理想臨界直径 $D_{\mathrm{I}}$ におよぼすオ ーステナイト結晶粒径の影響をコンピュータを使つて計 算した.

（1）すべての変態温度においてパーライト変態の機 構は同一不变である.つまり任意の温度 $T\left({ }^{\circ} \mathrm{C}\right)$ に扣け るパーライト変態率 $X_{\mathrm{P}}$ を次のように与えることができ る.

$$
\begin{aligned}
& X_{\mathrm{P}}=1-\exp \left(-k(T) \times \frac{t^{4}}{d^{1.76}}\right) \cdots \cdots \cdots \cdots \cdots \cdots \cdots(3) \\
& \text { ここで } k(T) \text { は変態温度 } T \text { のみに依存する係数で }
\end{aligned}
$$
ある.

（2）変態生成物はパーライトとマルテンサイトのみ である。
（1）の仮定は変態が isokinetic ${ }^{8)}$ であることを意味し 従つて自動的に加算則が成り立つ. (3) 式の $k(T)$ の 值は実測值より求められる。まず $720^{\circ} \mathrm{C}$ で等温変態さ せた場合, $18 \mathrm{~min}$ 保持することによりパーライト変態が 開始することを光学顕微鏡により観察したが，(2)式に $t=18 \mathrm{~min}, d=70.6 \mu \mathrm{m}\left(1100^{\circ} \mathrm{G}\right.$ でオーステナイト 化）を代入すると $X_{\mathrm{P}}=7.66 \times 10^{-4}$ となる. 光学顕微鏡 によつて決定した種々の温度に打沙るパーライト変態の 開始時間 (Fig.4) において変態率が $7.66 \times 10^{-4}$ 亿等 しいとすれば各温度での $k$ の值が求まる.このようにし て求めた $k$ の值を Table 4 に示す. $k$ は温度とともに 大きく变化するので自然対数をとり, $\ln k(T)$ を温度 $T$ の 2 次式で近似し, 最小自乗法により係数を決定し, 次 式を得た。

$$
\ln k(T)=-1.287 \times 10^{-3} T^{2}+1.843 T-671.2
$$

(3)式と (4) 式によつて任意のオーステナイト結晶粒度 に対する等温変態線図を計算により求めることができ る.たとえば $1100^{\circ} \mathrm{C}$ でオースナテイト化した場合 $(d=70.6 \mu \mathrm{m})$ の TTT 線図は Fig.13 のようにな る. 縦軸は変態温度 $\left({ }^{\circ} \mathbf{C}\right)$, 横軸は保持時間を対数で表 している. 図中の 4 つの曲線はパーライト変態量がそれ ぞれ $1 ， 10 ， 50,99 \%$ に達するまでの時間を表してい

Table 4. Calculated values of $k$.

\begin{tabular}{c|c|c}
\hline Temp. $\left({ }^{\circ} \mathrm{C}\right)$ & Time $(\min )$ & $k(T)$ \\
\hline 760 & 39 & $5.944 \times 10^{-7}$ \\
745 & 23 & $4.914 \times 10^{-6}$ \\
720 & 18 & $1.310 \times 10^{-5}$ \\
700 & 21 & $7.071 \times 10^{-6}$ \\
670 & 42 & $4.419 \times 10^{-7}$ \\
640 & 115 & $7.863 \times 10^{-9}$ \\
\hline
\end{tabular}

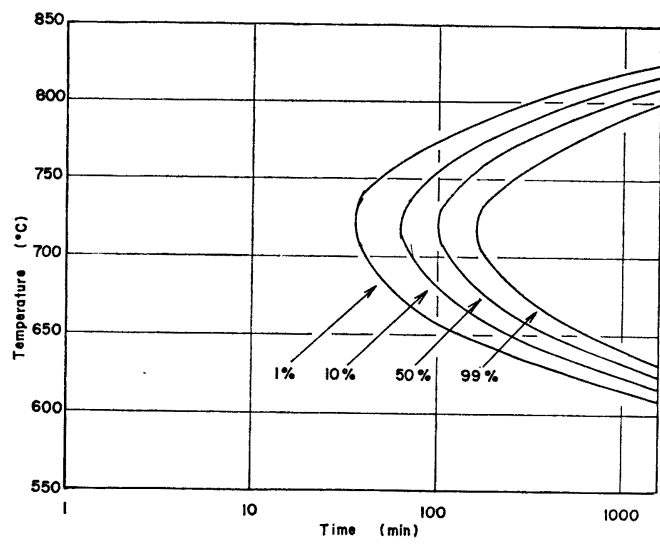

Fig. 13. Galculated TTT diagram by equation (3) and (4). Grain diameter $d=70.6 \mu \mathrm{m}$. 
る.（この TTT 線図は nose 温度付近では精確だが $670^{\circ} \mathrm{C}$ では実測值と比べるとパーライト量の多いところ で多少のずれを生じている．乙かし $D_{\mathrm{I}}$ の計算にあたつ ては nose 付近の変態が最も重要であるので $D_{\mathrm{I}}$ に対し てこのずれの影響は小さいと考えられる。)

次に丸棒を理想焼入した場合の中心部冷却曲線を求め る. 半径 $L$ の無限に長い丸棒を均一な温度 $T_{\mathrm{I}}$ に加熱し て (初期条件)，理想焼入れした場合を考える．理想焼入 れとは無限に大きな冷却能 $(H=\infty)$ で焼入れた場合であ り，焼入れた瞬間に鋼の表面温度が冷却剂の温度 $\left(T_{\mathrm{F}}\right)$ まで泠却され（境界条件）その後は鋼内部の熱伝導だけ によつて内部が冷却されるよらな場合を意味する。この 場合, 丸棒の中心から $r$ の距離の温度 $T$ は

$$
\frac{\partial^{2} T}{\partial r^{2}}+\frac{1}{r} \frac{\partial T}{\partial r}=\frac{1}{a^{2}} \frac{\partial T}{\partial t}
$$

なる式を満足している．ここで $a^{2}$ は鋼の熱拡散率であ る. 初期条件と境界条件を考虑して (5)式を解くと一般 化温度 $U=\left(T-T_{\mathrm{F}}\right) /\left(T_{\mathrm{I}}-T_{\mathrm{F}}\right)$ に対して

$$
U=\sum_{n=1}^{\infty} A_{n} J_{0}\left(k_{n} r\right) e^{-a^{2} k_{n}^{2} t}
$$

を得る。ここで $k_{n}$ は $J_{0}\left(k_{n} L\right)=0$ を満たすすべての 值でありまた $A_{n}=2 /\left(k_{n} L J_{1}\left(k_{n} L\right)\right)$ である. (6)式に $r=0$ (中心）を代入し変形すると

$$
T=T_{\mathrm{F}}+\left(T_{\mathrm{I}}-T_{\mathrm{F}}\right)\left(\sum_{n=1}^{\infty} A_{n} e^{-a^{2} k_{n}^{2} t}\right)
$$

となりこの式によつて任意の半径 $L$ の丸棒を理想焼入れ した場合の中心部の冷却曲線を計算することができる.

以上の任意のオーステナイト結晶粒径に対する等温線 図之半径 $L$ の丸棒の理想焼入時の中心部冷却曲線より加 算性を仮定した場合の理想臨界直径 $D_{\mathrm{I}}$ が計算できる.

Fig. 14 に計算のフローチャートを示す. まず時間を \lrcorner $t \mathrm{~s}$ ずつ進め, 中心部の温度 $T$ を計算する. 温度 $T$ が ある温度 (Fig.13 より $830^{\circ} \mathrm{C}$ とした) 以下の温度 $T_{1}$ に達したとき, 温度 $T_{1}$ に $\Delta t / 60 \mathrm{~min}$ 保持されるもの として $(3)$ 式によつてパーライト変態率 $X_{\mathrm{P}, \mathrm{T}_{1}}$ を計算す る. 次に時間を $\Delta t \mathrm{~s}$ だけ進めて中心部の温度 $T_{2}$ を計 算する.ささらに温度 $T_{2}$ でパーライト変態率が $X_{\mathrm{P}, \mathrm{T}_{1}}$ に 達するのに心要な時間 $D T$ を計算する. そして温度 $T_{2}$ に $(D T+\Delta t / 60) \min$ 保持されるものとしてパーライト 変態率 $X_{\mathrm{P}, \mathrm{T}}$ を計算する. 以下同様な計算を， $X_{\mathrm{P}}$ が 0.999 以上になるか，温度が十分に低温（ここでは 620 ${ }^{\circ} \mathrm{C}$ 以下とした）になるまでくり返す，そしてマルテン サイト変態量 $X_{\mathrm{M}}=100\left(1-X_{\mathrm{P}}\right)$ を計算して， $X_{\mathrm{M}}$ が50\% より大きければ半径Lを増加させ， $X_{\mathrm{M}}$ が $50 \%$ より小

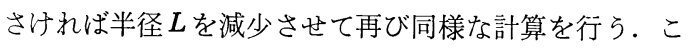
のようにして任意のオーステナイト結晶粒径に対する理

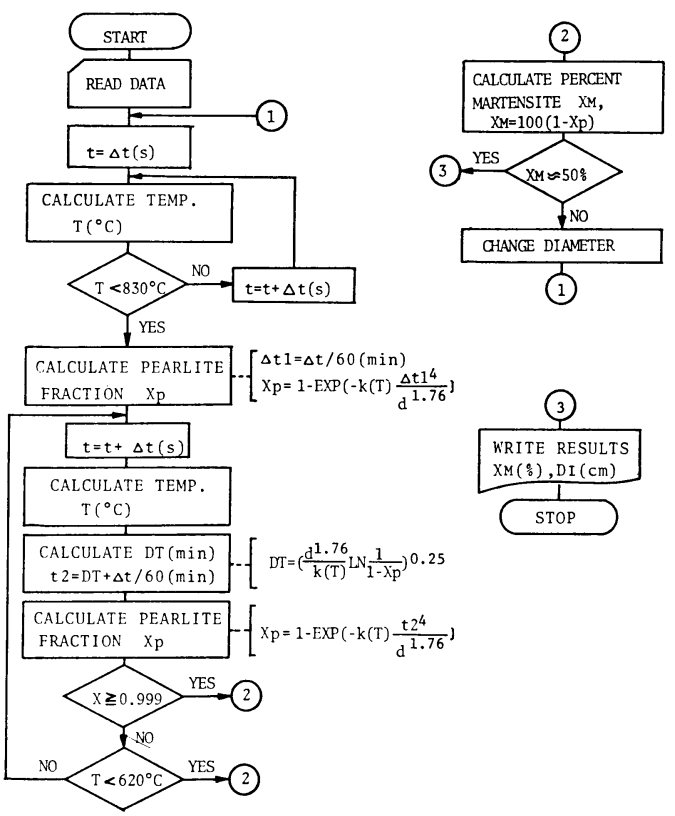

Fig. 14. Flow chart for the calculation of ideal critical diameter $D_{\mathrm{I}}$.

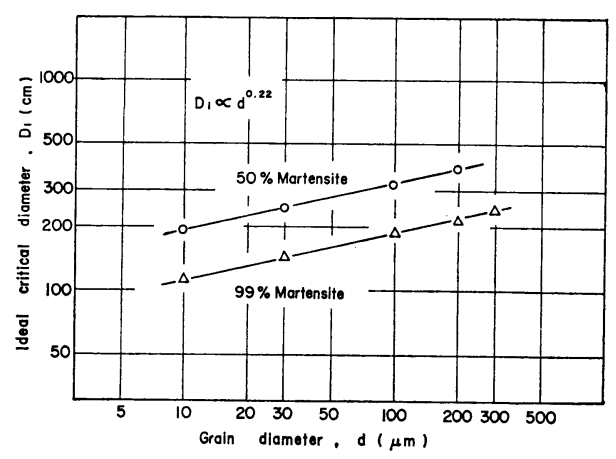

Fig. 15. Ideal critical diameter as a function of austenite grain size.

想臨界直径 $D_{\mathrm{I}}$ を計算することができる．Fig． 15 にこ のよらにして求めた理想臨界直径 $D_{\mathrm{I}}$ (中心部が $50 \%$ マ ルテンサイト）とオーステナイト結晶粒径との関係を示 す.この図に示された結果からオーステナイト結晶粒径 $d$ と理想臨界直径 $D_{\mathrm{I}}$ との間には

$$
D_{\mathrm{I}} \propto d^{\mathbf{0 . 2 2}} \text {. }
$$

なる関係があることが判明した. さらに Fig.15 には中 心部が $99 \%$ マルテンサイトになる直径も合わせて示し てあるがその直線の傾きからも明らかなように(8)式の 関係は丸棒中心部のマルテンサイト率には依存せずすべ てのマルテンサイト率に対して成り立つことがわかる. 
そして計算過程全体からみて，(8)式の関係は変態機構 (site saturation か nucleation and growth か) 及び核 生成場所のみによつて決まり, nose の温度や变態の速度 にも無関係であることがわかる，ところで本研究で求め た (8) 式の関係は GROSSMANN ${ }^{113)}$ らが種々の共析及び 亜共析鋼について実験より求めた理想臨界直径とオース テナイト結晶粒径の関係 $D_{\mathrm{I}} \propto d^{0.23}$ に極めて近く, こ のことは本研究での計算方法が妥当なるのであることを 示している.

次にこれまであまり定量的に明らかでなかつた理想焼 入した丸棒中心部のマルテンサイト量と丸棒の直径の関 係について考察した、今等温に扣けるパーライト変態が すべての温度で

$$
X_{\mathrm{P}}=1-\exp \left(-k(T) \cdot t^{n}\right.
$$

で与えられる（つまり $n$ が温度に依存しない）場合には 各温度に拊ける变態の間に加算則が成立する。したがつ て温度 $T$ で等温变態させた場合，パーライト変態率が $X_{P}^{\circ}$ に達するまでの時間を $t_{\mathrm{X}_{\mathrm{p}}^{\circ}}(T)$ とするとある冷却 $T(t)$ が

$$
\int \frac{1}{t_{\mathrm{X} \dot{P}}(T)} \cdot \frac{d t}{d T(t)} d T(t)=1
$$

を満足する場合，その冷却によつて得られるパーライト 量は $X_{\mathrm{P}}^{\circ}$ となる。ところで理想焼入れした場合，冷却速 度は丸棒の直径 $D$ の自乗に逆比例するから

$$
\frac{d T(t)}{d t}=\frac{Q(T)}{D^{2}}
$$

なる関係がある.ここで $Q(T)$ は直径に依存しない関数 である。また $(9)$ 式より

$$
t_{\mathbf{X}_{\mathrm{P}}^{\circ}}(T)=\frac{1}{k(T)^{1 / n}}\left(\ln \frac{1}{1-X_{\mathrm{P}}}\right)^{1 / n} .
$$

と表されるから（10）式に（11）式と（9'）式を代入 して

$$
\begin{aligned}
& \int \frac{D^{2}}{\left(\ln \frac{1}{1-X_{\mathrm{P}}^{\circ}}\right)^{1 / n}} \cdot \frac{k(T)^{1 / n}}{Q(T)} d T=\frac{D^{2}}{\left(\ln \frac{1}{1-X_{\mathrm{P}}^{\circ}}\right)^{1 / n}} \\
& \times \int \frac{k(T)^{1 / n}}{Q(T)} d T=1
\end{aligned}
$$

ところで $\int \frac{k(T)^{1 / n}}{Q(T)} d T=$ 一定であるから

$\left(\ln \frac{1}{1-X_{\mathrm{P}}^{\circ}}\right)^{1 / n}=$ 一定となる.

今パーライト変態後の残りのオーステナイトがすべてマ ルテンサイトに変態した場合, マルテンサイトの变態率

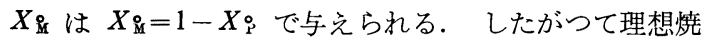
入れした場合の中心部のマルテンサイト率 $X_{\text {品 とその時 }}$ の丸棒の直径 $D_{\mathrm{I}, ~} X_{\text {品 }}$ との間には

$$
D_{\mathrm{I}, \mathrm{X}}^{\circ} \propto\left(\ln 1 / X_{\mathrm{M}}^{\circ}\right)^{1 / 2 n}
$$

なる関係が成り立つ. 本研究に使用した試料は前述のご とく $n=4$ であるので

$$
D_{\mathrm{I}, X_{\mathrm{M}}^{\circ}} \propto\left(\ln 1 / X_{\mathrm{M}}^{\circ}\right)^{1 / 8}
$$

なる関係のあることがわかる．さらにこの式から中心部

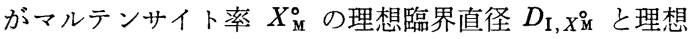
臨界直径 $D_{\mathrm{I}}$ との間には

$$
D_{\mathrm{I}, X_{\mathrm{M}}^{\circ}}=\left(\frac{\ln X_{\mathrm{Q}}^{\circ}}{\ln 0.5}\right)^{1 / 8} \cdot D_{\mathrm{I}} \cdots
$$

なる式が成り立ち，これを使つて $D_{\mathrm{I}}$ がわかつている鋼 について中心部のマルテンサイト率を任意に取つた場合 の理想臨界直径が計算できる.

以上本研究では等温変態に打いて得られたデータを連 続冷却変態に拡張することによつてオーステナイト粒径 と $D_{\mathrm{I}}$ 及び中心部がマルテンサイト率 $X_{\text {M }}^{\circ}$ の理想臨界 直径 $D_{\mathrm{I}, X \mathrm{i}}$ と $D_{\mathrm{I}}$ の関係を導いたが，このような等温 変態から焼入性を予測する方法は実験が比較的容易な等 温で扢こなえ，理論的解秎が可能で，またこれまで得ら れている等温変態での多くの理論やデータを活用できる といら大きな利点がある。ささらに冷却についてもとの冷 却曲線さえわかればどのよらな複雑な冷却に対しても最 終的に得られる変態量を精密に計算でき又冷却途中での 刻々の組織変化がとらえられ焼割れの予測といつた問題 にも応用が可能である。これらについては後報14にゆず る.

\section{4. 結言}

鋼の焼入性を相変態理論にのつとり理論的に予測する 方法を見出す目的でまず共析鋼の焼入性におよぼすオー ステナイト粒径の影響をとりあげた，等温変態に沶いて パーライト変態に拈よぼすオーステナイト粒径の影響を 測定し，それを連続冷却变態に恋換する方法を検討し， 理想臨界直径に打よぼすオーステナイト粒径の影響をコ ンピュータによる計算から求めた。得られた主な結果は 次のとおりである.

（1）本研究で使用した鋼のパーライト変態率 $X$ は (2)式で与えられる.このことはパーライト反応が核生 成を伴いながら進行しその主たる核生成場所が grain edge であると理解できる。

（2） step quench によりパーライト変態の kinetiscs に拈ける加算性について調べた結果変態途中で温度を変 化させると変態の進行はわずかに遅くなるが，加算性が ほ涪成り立つ。

(3) (1) (2)の結果よりパーライト変態の変態機構が すべての変態温度で同一であると仮定した場合理想臨界 
直径とオーステナイト粒径の間には $(8)$ 式なる関係があ る. この関係は変態機構と核生成場所のみによつて決ま る.

（4） 理想焼入した丸棒の中心のマルテンサイト率 $X$ とその時の丸棒の直径 $D_{\mathrm{I}, X}$ との間には (12) 式なる関係 が成立する。

\section{交献}

1) $M . A \cdot$ Grossmann: "Elements of Hardenability" (1952) Cleveland [ASM]

2 ) I. R. Kramer, S. Siegel, and J. G. Brooks: Trans. AIME. $167(1946)$, p. 670

3 ) R. A. Grange: Met. Trans., 4(1973), p. 2231

4) J. Glen: Brit. Iron Steel Inst. Spe. Rep. (1945) 36
5 ) J.W. Cahn: Acta Met., 4(1956), p. 449

6) J.W. GAHN: Acta Met., 4(1956), p. 572

7 ) K. O. Russel: Acta Met., 17(1969), p. 1123

8 ) M. Avrami: J. Chem. Phys. 7(1939), p. 1103, $8(1940)$, p. 212

9 ) $W$. A. Johnson and $R$. F. Mehl: Trans. AIME 135 (1939), p. 416

10) D. Turnbull: Acta Met., 3(1955), p. 55

11) J. S. Kirkaldy: Met. Trans. 4(1973), p. 2327

12) E. SaheIL: Arch. Eisenhüttenw., 12(1935), p. 565

13) $M . A$. Grossmann and $R . L$. Stephenson: Trans. ASM 29(1941), p. 1

14）梅本 実, 小松原望, 田村今男: J. Heat Treating に投稿予定 